\title{
Real-Time PCR Assays for the Detection of Puccinia psidii
}

J. Baskarathevan, R. K. Taylor, and W. Ho, Plant Health and Environment Laboratory, Ministry for Primary Industries, Auckland 1140, New Zealand; R. L. McDougal, Scion, New Zealand Forest Research Institute Ltd., Rotorua, 3046, New Zealand; R. G. Shivas, Plant Pathology Herbarium, Biosecurity Queensland, Department of Agriculture, Fisheries and Forestry, Brisbane 4001, Queensland, Australia; and B. J. R. Alexander, Plant Health and Environment Laboratory, Ministry for Primary Industries, Auckland 1140, New Zealand

\begin{abstract}
Baskarathevan, J., Taylor, R. K., Ho, W., McDougal, R. L., Shivas, R. G., and Alexander, B. J. R. 2016. Real-time PCR assays for the detection of Puccinia psidii. Plant Dis. 100:617-624.

Puccinia psidii (Myrtle rust) is an emerging pathogen that has a wide host range in the Myrtaceae family; it continues to show an increase in geographic range and is considered to be a significant threat to Myrtaceae plants worldwide. In this study, we describe the development and validation of three novel real-time polymerase reaction (qPCR) assays using ribosomal DNA and $\beta$-tubulin gene sequences to detect $P$. psidii. All qPCR assays were able to detect $P$. psidii DNA extracted from urediniospores and from infected plants, including asymptomatic leaf tissues. Depending on the gene target, qPCR was able to detect down to $0.011 \mathrm{pg}$ of $P$. psidii DNA.

The most optimum qPCR assay was shown to be highly specific, repeatable, and reproducible following testing using different qPCR reagents and real-time PCR platforms in different laboratories. In addition, a duplex qPCR assay was developed to allow coamplification of the cytochrome oxidase gene from host plants for use as an internal PCR control. The most optimum qPCR assay proved to be faster and more sensitive than the previously published nested PCR assay and will be particularly useful for high-throughput testing and to detect $P$. psidii at the early stages of infection, before the development of sporulating rust pustules.
\end{abstract}

Puccinia psidii G. Winter is a biotrophic fungal pathogen causing a serious rust disease (also known as guava rust, eucalyptus rust, myrtle rust, or ohia rust) on a wide range of plant species in several genera of Myrtaceae (Langrell et al. 2008). P. psidii was first reported in Brazil in 1884 (Winter 1884), and then spread to other South and Central American countries. Later, spread of $P$. psidii has been reported from different states in the United States, including California, Florida (Rayachhetry et al. 1997), and Hawaii (Uchida et al. 2006). Recently, this pathogen has been reported from different countries on different continents, including Japan (Kawanishi et al. 2009), Australia (Carnegie et al. 2010), China (Zhuang and Wei 2011), South Africa (Roux et al. 2013), and New Caledonia (Giblin 2013). The recent emergence of this pathogen and its vigorous spread threatens species in the Myrtaceae family worldwide, including endemic species in many countries (Carnegie and Lidbetter 2012; Coutinho et al. 1998; Glen et al. 2007; Tommerup et al. 2003). New Zealand is free from $P$. psidii but it is feared that this rust may arrive in the near future because rust spores have been reported to travel long distances on wind currents. For example, cereal and poplar rusts were shown to be introduced into New Zealand from Australia by wind currents (Viljanen-Rollinson and Cromey 2002; Wilkinson and Spiers 1976).

Unlike most rust species, $P$. psidii has a wide host range (Carnegie and Lidbetter 2012). Since it was found in New South Wales, Australia in early 2010, the host range increased from 100 to more than 400 species (Giblin and Carnegie 2014; Simpson et al. 2006), causing a significant impact on the environment, economy, and community (Carnegie and Cooper 2011). P. psidii has caused significant economic impacts on Eucalyptus (Furtado and Marino 2003) and guava (Martins et al. 2011) plantations in South America, where outbreaks have resulted in 50 to $80 \%$ loss of production. Long-term impacts are likely to affect many industries such as nursery and garden, cut flower and foliage, forestry and timber, honey and pollination,

Corresponding author: J. Baskarathevan;

E-mail: Jeyaseelan.Baskarathevan@mpi.govt.nz

Accepted for publication 16 October 2015.

http://dx.doi.org/10.1094/PDIS-08-15-0851-RE

(C) 2016 The American Phytopathological Society bush foods and medicines, and revegetation and tourism. Like many other rust fungi, $P$. psidii is easily spread by dissemination of infectious urediniospores by wind, rain, and insects. Since the first detection of $P$. psidii in Australia, the fungus has spread rapidly along the eastern coast, likely due to the large number of airborne spores produced (Carnegie et al. 2010). Once $P$. psidii has been introduced and established, it is very difficult to contain and to prevent further spread. The long-distance spread of this fungus is likely to occur via urediniospores on imported nursery stocks or contaminated clothing. Conventional diagnosis of $P$. psidii relies on symptom observations, host identification, and microscopic examination of sporulating rust pustules and spores. However, it is difficult to identify myrtle rust based on early symptoms because the characteristic rust pustules may be absent. Moreover, $P$. psidii can cause a diverse range of early symptoms depending on host susceptibility and environmental conditions (Glen et al. 2007); therefore, morphological identification can be difficult and time consuming because it requires specialized expertise. Because any delay in pathogen identification may reduce the probability of successful containment or eradication, it is important to have alternative detection methods.

Identification of plant pathogens using molecular methods offers several advantages over traditional methods of diagnosis. Polymerase chain reaction (PCR)-based detection methods have made a significant contribution to eliminate some of the problems associated with the detection, control, and containment of plant pathogens (Henson and French 1993). The internal transcribed spacer (ITS) regions within the nuclear ribosome-encoding gene (rDNA) have been widely used in fungal taxonomy. including several species in genus Puccinia Pers. (Anikster et al. 2004; Kropp et al. 1997; Zambino and Szabo 1993). Furthermore, the rDNA gene is the most commonly sequenced for rust species to study their genetic relationships in rust fungi (Aime 2006). In addition, the high copy number of ITS regions in the fungal genome (Ganley and Kobayashi 2007) enables sensitive PCR amplification.

There is only one published PCR assay to detect $P$. psidii, where the ITS region was used to design a species-specific nested PCR assay (Langrell et al. 2008). This nested PCR assay required two rounds of PCR amplifications and gel electrophoresis to confirm the identity of $P$. psidii. The nested PCR approach can take up to $9 \mathrm{~h}$ following receipt of suspect infected tissue. An alternative to conventional PCR detection is the use of real-time PCR (qPCR), which 
allows accurate detection and quantification of plant pathogens (Capote et al. 2012). In addition, qPCR is highly sensitive and faster than conventional PCR, enabling the use of qPCR for highthroughput detection of plant pathogens.

Currently, there is no qPCR assay available for P. psidii. Accordingly, the objectives of this study were the development and validation of novel qPCR primers and hydrolysis probes for sensitive and fast detection of $P$. psidii in plant tissue.

\section{Materials and Methods}

$P$. psidii DNA extraction and infected plant specimens. The qPCR assays were developed using DNA extracted from urediniospores of $P$. psidii collected from infected plants in Brazil, Hawaii, and Australia (Table 1). Further testing and validation of the qPCR assays were then conducted on $P$. psidii-infected leaves collected in Australia and from herbarium specimens obtained from New Caledonia (Table 1).

Two DNA extraction methods were used to extract DNA from $P$. psidii-infected plant tissues. The DNeasy Plant Mini kit (Qiagen) method was used to extract DNA from field-collected, $P$. psidiiinfected leaf tissues of Rhodomyrtus psidioides (native guava) and Rhodamnia rubescens (scrub turpentine). Leaves with different levels of $P$. psidii infection ranging from nonsymptomatic to heavily infected were used to extract DNA to test the detection sensitivity of the qPCR assays (Fig. 1). Four leaf tissue sections (approximately 5 by $5 \mathrm{~mm}$, containing rust pustules) were taken from an infected leaf and added into a 2-ml screw-capped tube containing a single chromo steel bead (3.2 $\mathrm{mm}$ in diameter). The samples were macerated for 2 min using a TissueLyser II (Qiagen) and then $600 \mu$ l of cetyltrimethylammonium bromide (CTAB) lysis buffer $(2.0 \%$ CTAB, $1.4 \mathrm{M}$ $\mathrm{NaCl}, 20 \mathrm{mM}$ EDTA, $100 \mathrm{mM}$ Tris- $\mathrm{HCl}$ [pH 8.0], and 1.0\% polyvinylpyrolidone) was added, mixed by inversion several times, and incubated at $65^{\circ} \mathrm{C}$ for $25 \mathrm{~min}$, with occasional shaking for $20 \mathrm{~s}$ at 2-min intervals using a Thermomixer (Eppendorf). The samples were centrifuged at 13,000 rpm for $3 \mathrm{~min}$, and $500 \mu$ l of supernatant was transferred to a new tube and purified according to the manufacturer's instructions.

An automated KingFisher (Thermo Scientific) nucleic acid extraction system with the InviMag plant DNA mini kit (Invitek) was also used to extract DNA from myrtle-rust-infected herbarium materials of Syzygium jambos (rose apple) and Eugenia gocognei (eugenia). Approximately $300 \mathrm{mg}$ of leaf tissue with rust pustules was placed in an extraction bag (Bioreba) with $3 \mathrm{ml}$ of CTAB lysis buffer. An automatic Homex grinder (Lenze) was used to grind the leaf tissue completely. Approximately $1.5 \mathrm{ml}$ of the homogenized sample was incubated at $65^{\circ} \mathrm{C}$ for $25 \mathrm{~min}$ with occasional shaking for $20 \mathrm{~s}$ at 2-min intervals using a Thermomixer. Subsequently, the samples were centrifuged at 13,000 rpm for $3 \mathrm{~min}$, and $420 \mu \mathrm{l}$ of supernatant was used to perform DNA extraction using the KingFisher system with InviMag plant DNA mini kit (Invitek), according to the manufacturer's instructions. This method was also used to extract DNA from healthy Myrtaceae plant leaves (Table 2). Prior to qPCR tests, the concentration of all $P$. psidii DNA samples and all DNA extractions from infected samples were quantified using a NanoDrop ND1000 spectrophotometer (Thermo Scientific). The DNA samples were stored at $-80^{\circ} \mathrm{C}$ until use for PCR applications.

Design of species-specific primers and TaqMan probes. In total, 46 complete ITS $P$. psidii sequences and four $\beta$-tubulin gene sequences of $P$. psidii were retrieved from GenBank (National Center for Biotechnology Information) and analyzed using Geneious software (Geneious Pro 5.5.6; Biomatters Ltd). Multiple forward and reverse primers and hydrolysis probes (TaqMan) were designed for
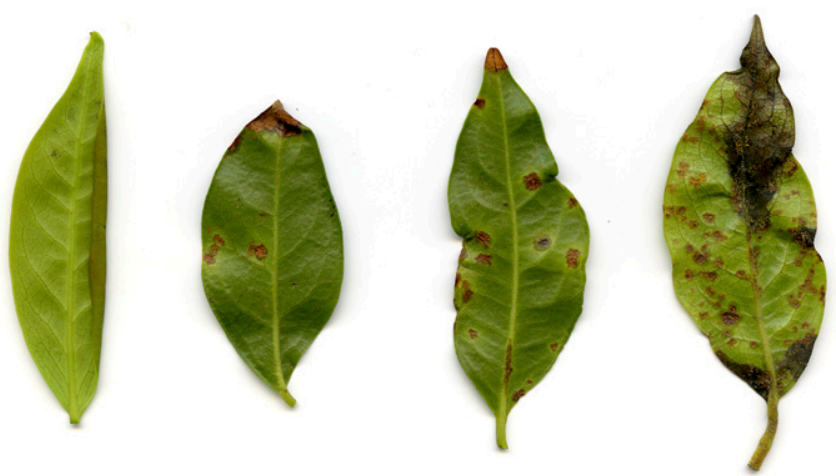

Fig. 1. Rhodomyrtus psidioides leaves with different levels of Puccinia psidii infection used for DNA extractions.

Table 1. Isolates of Puccinia spp. used in this study

\begin{tabular}{|c|c|c|c|c|}
\hline Species & voucher & Host & DNA from & Origin \\
\hline Puccinia psidii & UFV-2 & Eucalyptus sp. & Urediniospores & Brazil \\
\hline P. psidii & SUZ-14 & Syzygium jambos & Urediniospores & Brazil \\
\hline P. psidii & RJ-9 & Psidium guajava & Urediniospores & Brazil \\
\hline P. psidii & HW-1 & S. jambos & Urediniospores & Hawaii \\
\hline P. psidii & HW-2 & S. paniculatum & Urediniospores & Hawaii \\
\hline P. psidii & BRIP 57997 & Eugenia reinwardtiana & Urediniospores & Australia \\
\hline P. psidii & BRIP 57991 & Melaleuca leucadendra & Urediniospores & Australia \\
\hline P. psidii & BRIP 57985 & S. jambos & Urediniospores & Australia \\
\hline P. psidii & BRIP 57793 & Rhodamnia angustifolia & Urediniospores & Australia \\
\hline P. psidii & BRIP 57922 & M. quinquenervia & Urediniospores & Australia \\
\hline P. psidii & BRIP 58000 & Rhodamnia rubescens & Urediniospores & Australia \\
\hline P. psidii & BRIP 58037 & Backhousia citriodora & Urediniospores & Australia \\
\hline P. psidii & BRIP 58038 & M. viridiflora & Urediniospores & Australia \\
\hline P. psidii & BRIP 58511 & Rhodomyrtus psidioides & Infected tissue & Australia \\
\hline P. psidii & BRIP 58513 & Rhodamnia rubescens & Infected tissue & Australia \\
\hline P. psidii & T13_03489A & S. jambos & Infected tissue $\mathrm{a}^{\mathrm{a}}$ & New Caledonia \\
\hline P. psidii & T13_03489B & E. gacognei & Infected tissue $\mathrm{e}^{\mathrm{a}}$ & New Caledonia \\
\hline P. graminis & PDD101636 & Festuca arundinacea & Urediniospores & New Zealand \\
\hline P. striiformis & PDD101676 & Dactylis glomerata & Urediniospores & New Zealand \\
\hline P. hordi & MP273 & Holcus lanatus & Urediniospores & New Zealand \\
\hline P. hemerocallidis & PDD102320 & Hemerocallis sp. & Urediniospores & New Zealand \\
\hline P. oxalidis & Unknown & Oxalis sp. & Urediniospores & New Zealand \\
\hline$P$. coronata & T12_03234 & Lolium sp. & Urediniospores & New Zealand \\
\hline P. myrsiphylli & T10_03433A & Asparagus asparagoides & Urediniospores & New Zealand \\
\hline
\end{tabular}

${ }^{a}$ Herbarium specimens obtained from New Caledonia. 
ITS and $\beta$-tubulin consensus sequences using Beacon Designer 8.01 software (Premier Biosoft) with default settings for standard TaqMan design. The primers and probes were evaluated in silico for potential secondary structures using a Beacon Designer in order to select suitable forward and reverse primer combinations. Primer pairs were selected to amplify a very short PCR fragment $(<200 \mathrm{bp})$, because they amplify more efficiently and are more tolerant of reaction conditions. The hydrolysis probes were designed with 6-carboxy-fluorescein (FAM) fluorophore at the $5^{\prime}$ end and Black Hole Quencher-1 (BHQ-1) at the $3^{\prime}$ end. The specificity of the ITS and $\beta$-tubulin primers and probes was evaluated by in silico analysis using a BLASTn search. Only primers and probes with high specificity to $P$. psidii were synthesized by BioSearch Technologies and used in this study (Table 3 ).

Development and optimization of qPCR assays. The $P$. psidii qPCR assays were performed using a LightCycler 480 Probes Master PCR Mix (Roche). All the qPCR assays were carried out in a final volume of $20 \mu \mathrm{l}$ : $10 \mu \mathrm{l}$ of $2 \times$ reaction buffer, a final concentration of $300 \mathrm{nM}$ each specific forward and reverse primer, $120 \mathrm{nM}$ FAM- or BHQ-labeled TaqMan probe (Table 3), bovine serum albumen at $0.5 \mu \mathrm{g} / \mu \mathrm{l}, \mathrm{MgCl}_{2}$ (5 mM final), and $2 \mu \mathrm{l}$ of DNA template. Thermocycling conditions were as follows: $95^{\circ} \mathrm{C}$ for $3 \mathrm{~min}$, then 40 cycles of $95^{\circ} \mathrm{C}$ for $15 \mathrm{~s}$ and $60^{\circ} \mathrm{C}$ for $45 \mathrm{~s}$. All three qPCR assays were further optimized with the addition of extra $\mathrm{MgCl}_{2}(4.2$ to $6.2 \mathrm{mM}$ final concentration) and gradient qPCR $\left(55\right.$ to $\left.65^{\circ} \mathrm{C}\right)$ to obtain an optimum annealing temperature for each assay. The PCR amplification quality of the DNA extracted from healthy and $P$. psidii-infected plant tissues was checked by using plant internal control primers and probes that target the cytochrome oxidase (cox) gene (Weller et al. 2000) using the above PCR reagents and conditions.

Specificity and analytical sensitivity of qPCR assays. Specificity of the three qPCR assays were tested against all Puccinia isolates in Table 1 and against 13 plant species in the Myrtaceae family commonly found in New Zealand (Table 2). The sensitivity of all three qPCR assays was evaluated using 10-fold serial dilutions of $P$. psidii genomic DNA from known concentrations prepared in sterile water.

Table 2. Healthy Myrtaceae plants species tested for specificity of real-time polymerase chain reaction assays

\begin{tabular}{ll}
\hline Common name & \multicolumn{1}{c}{ Scientific name } \\
\hline Acmena & Syzygium smithii \\
Agonis & Agonis fleuosa \\
Bottle bush & Callistemon $\mathrm{sp}$. \\
Eucalyptus & Eucalyptus sp. \\
Eugina & Syzygium smithii \\
Fijoa & Acca sellowlana \\
Guava & Psidium cattleianum \\
Kanuka & Kunzea ericoides \\
Manuka & Leptospermum scoparium \\
Melaleuca & Melaleuca sp. \\
Pohutukawa & Metrosideros excelsa \\
Ramarama & Lophomyrtus bullata \\
Rata & Metrosideros carminea \\
\hline
\end{tabular}

The detection sensitivity of the qPCR assays was also tested against $P$. psidii genomic DNA $(0.5 \mathrm{ng} / \mu \mathrm{l})$ spiked into healthy Eucalyptus sp. DNA $(35 \mathrm{ng} / \mu \mathrm{l})$ at different ratios from 1:1 to 1:20 (P. psidii/Eucalyptus sp.). The sensitivities of the qPCR assays were then further compared against an existing conventional nested PCR detection tool for $P$. psidii using the method developed by Langrell et al. (2008). The same 10-fold serial dilutions of $P$. psidii genomic DNA of known concentrations prepared in sterile water were used as templates for a nested PCR assay for comparison.

In planta detection of $P$. psidii was assessed by selecting the qPCR assay with the greatest detection sensitivity to test rust-infected plant materials collected in Australia and New Caledonia. The qPCR assay PpsiITS1 (with primer pair PpsiITS1F/PpsiITS1R and TaqMan probe PpsiITS1P) was used to detect $P$. psidii from 40 DNA extractions from myrtle-rust-infected plants of Rhodomyrtus psidioides and Rhodamnia rubescens from Australia and four DNA extractions from myrtle-rust-infected herbarium material of $S$. jambos and $E$. gocognei from New Caledonia. These DNA extracts from rustinfected plant tissues were also tested with the conventional nested PCR assay (Langrell et al. 2008).

Assay repeatability and reproducibility. Assay repeatability and reproducibility were determined for the qPCR assay PpsiITS 1 by calculating percent coefficient of variation $(\% \mathrm{CV})$ for intra- and interassay using the mean cycle threshold $(\mathrm{Ct})$ values and standard deviations. To assess repeatability, the intraassay $\mathrm{CV}$ was calculated from eight replicates of three dilutions $(500,5$, and $0.5 \mathrm{pg} / \mu \mathrm{l})$ of $P$. psidii DNA extracted from urediniospores tested in the same run.

The assay reproducibility was assessed by calculating interassay $\mathrm{CV}$ from three consecutive qPCR runs performed on different days by three different operators. To demonstrate transfer of the assay to other laboratories, reproducibility was assessed by using different reagents and real-time PCR machines in different laboratories in New Zealand.

Development of duplex assay. A duplex qPCR assay was then developed to coamplify $P$. psidii DNA with the plant cox gene as an internal control. This duplex qPCR was developed using primers PpsiITS1F and PpsiITS1R and probe PpsiITS1P (Table 3) and the cox gene-specific primers and probe (Weller et al. 2000). The duplex qPCR was performed using a PerfeCTa qPCR ToughMix (Quanta Biosciences) and with an additional PCR reagent "COX BLOCK" (dNature Diagnostics \& Research Ltd.). The COX BLOCK is specific to the internal control (cox gene) amplicon and is used to delay the amplification of the cox gene, thereby preventing the internal control from outcompeting the detection of $P$. psidii DNA. The duplex qPCR assay was carried out in a final volume of $20 \mu \mathrm{l}: 10 \mu \mathrm{l}$ of $2 \times$ ToughMix, a final concentration of $300 \mathrm{nM}$ each specific forward and reverse primer for $P$. psidii and the cox gene, $120 \mathrm{nM}$ FAMlabeled TaqMan probe for $P$. psidii and $100 \mathrm{nM}$ CAL Fluor Red 610-labeled TaqMan probe for the cox gene, with 0, 300, 500, and $750 \mathrm{nM}$ concentrations of COX BLOCK and $2 \mu \mathrm{l}$ of DNA template. The thermocycling conditions used were as follows: $95^{\circ} \mathrm{C}$ for $3 \mathrm{~min}$, then 40 cycles of $95^{\circ} \mathrm{C}$ for $5 \mathrm{~s}$ and $59^{\circ} \mathrm{C}$ for $30 \mathrm{~s}$. Tenfold serial dilutions of $P$. psidii DNA spiked with healthy Eucalyptus sp. DNA as diluents were used as template for duplex qPCR assay to determine an optimum COX BLOCK concentration at which the

Table 3. Puccinia psidii-specific primers and TaqMan probes used in this study

\begin{tabular}{|c|c|c|c|}
\hline Assay name & Primer, probe ${ }^{a}$ & Sequence $\left(5^{\prime}-3^{\prime}\right)$ & Target \\
\hline \multirow{3}{*}{ PpsiITS1 } & PpsiITS1F & GTAGCTTTATTGAAACATAGTAA & ITS1 \\
\hline & PpsitTS1R & TGATTTTAGACAATAATAATAAGGG & $\ldots$ \\
\hline & PpsiITS1P & FAM-AGATTAATATCTTTGCCACGTATACCA-BHQ1 & $\ldots$ \\
\hline \multirow[t]{3}{*}{ PpsiITS2 } & PpsiITS2F & ACСАСТTCTACCTTATTACA & ITS1 \\
\hline & PpsiITS2R & GGGTAATGTGACAAAGAT & $\ldots$ \\
\hline & PpsiITS2P & FAM-TGCCACGTATACCAAATTACTATGTTT-BHQ1 & $\ldots$ \\
\hline \multirow[t]{3}{*}{ PpsiBT1 } & PpsiBT1F & AGGTCAACTCAACTCTGA & $\beta$-Tubulin \\
\hline & PpsiBT1R & GAGGTTAGCTCTGGTACA & $\ldots$ \\
\hline & PpsiBT1P & FAM-ACGATATTGCTGGCTACCACGA-BHQ1 & $\ldots$ \\
\hline
\end{tabular}

${ }^{\mathrm{a}} \mathrm{F}=$ forward primer, $\mathrm{R}=$ reverse primer, and $\mathrm{P}=$ TaqMan probe. 
target $\mathrm{Ct}$ values are comparable in both single and duplex qPCR assays. The $\mathrm{Ct}$ values obtained for the target (P. psidii) and cox gene amplifications were compared between single and duplex qPCR assays. The optimized duplex qPCR assay for $P$. psidii and the cox gene was then tested using DNA extracted from naturally myrtle-rustinfected plant tissues.

\section{Results}

$\boldsymbol{P}$. psidii-specific primers and probes. Three new sets of qPCR primers and probes, including two from the ITS region and one from the $\beta$-tubulin gene, were designed for $P$. psidii in this study. The amplified ITS1 and the $\beta$-tubulin regions were found to be highly conserved within the $P$. psidii population. The in silico BLASTn analysis confirmed that the newly designed primer and probe sequences were specific (100\% homology) to the target species $P$. psidii only.

Development of $P$. psidii qPCR assays. The designed qPCR primers and probes with LightCycler 480 Probes Master Mix specifically amplified the $P$. psidii target sequence only. For qPCR assays PpsiITS1 and PpsiITS2, optimum amplification was achieved by the addition of $\mathrm{MgCl}_{2}$ (4.2 $\mathrm{mM}$ final concentration). However, additional $\mathrm{MgCl}_{2}$ did not change the amplification performance of the $\beta$-tubulin qPCR assay. Optimum annealing temperatures were identified in gradient qPCR assays for PpsiITS1 and PpsiITS2 qPCR assays at $59^{\circ} \mathrm{C}$ and for the PpsiBT1 assay at $60^{\circ} \mathrm{C}$. All three qPCR-amplified products were analyzed in gel electrophoresis and this confirmed that all amplifications resulted in a single PCR product, as expected (data not shown). The sequence analysis of the amplified PCR products of these three qPCR assays showed that all amplicons were $100 \%$ identical to $P$. psidii sequences in GenBank (AJ421800 and EU487246).

Specificity of $\boldsymbol{P}$. psidii qPCR assays. Specificity tests of qPCR assays PpsiITS1, PpsiITS2, and PpsiBT1 against $13 P$. psidii isolates from different countries confirmed that these assays were able to detect all $P$. psidii strains regardless of their geographical origin. No cross amplifications were produced in any of the other seven Puccinia spp. tested in this study. Specificity tests of the qPCR assays PpsiITS1, PpsiITS2, and PpsiBT1 against 13 plant species in the Myrtaceae family present in New Zealand did not cross amplify.

Sensitivity of qPCR assays. Analytical sensitivities for qPCR assays PpsiITS1 and PpsiITS2 were 0.011 and 1.1 pg of $P$. psidii genomic DNA, respectively. This result showed that the qPCR assay PpsiITS1 was at least 100 times more sensitive than the PpsiITS2 assay. The analytical sensitivity obtained for qPCR assay PpsiBT1 was $110 \mathrm{pg}$ of $P$. psidii DNA (Fig. 2). The conventional nested PCR assay detected down to $1.1 \mathrm{pg}$ of P. psidii DNA (Fig. 3). The sensitivity obtained for the conventional nested PCR was equal to the sensitivity

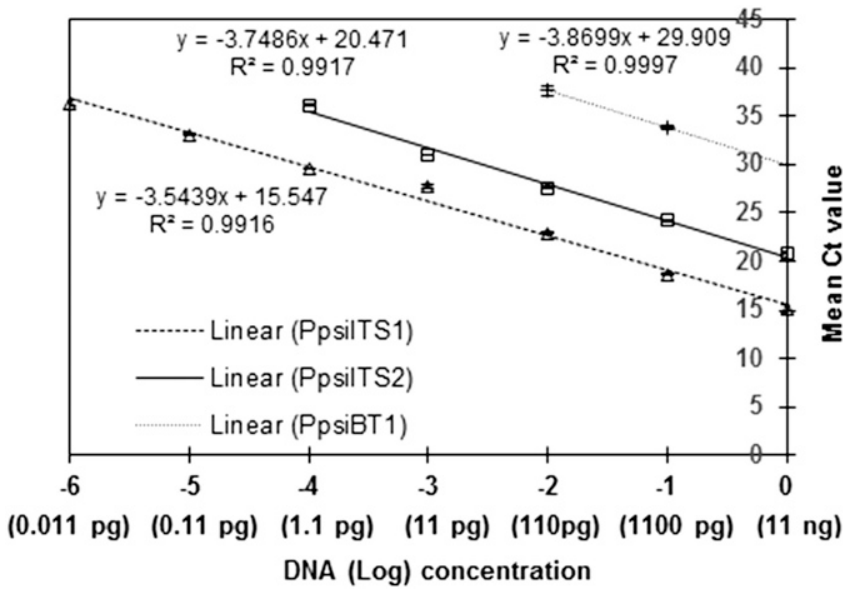

Fig. 2. Sensitivities of the Puccinia psidii real-time polymerase chain reaction assays (PpsilTs1, PpsilTS2, and PpsiBT1) for detecting P. psidii using seven 10-fold serial dilutions $(n=3)$ of purified DNA. Coefficients of determination $R^{2}$ and the slopes of each regression curve are indicated; $\mathrm{Ct}=$ cycle threshold. of the qPCR assay PpsiITS2 and was 100-fold less sensitive than the qPCR assay PpsiTTS1.

All three qPCR assays were able to detect $P$. psidii in the presence of host (Eucalyptus sp.) DNA down to a 1:20 dilution (Table 4). These results show that all three qPCR assays were sensitive enough to detect $P$. psidii in host tissues. Similar to previous results, the $\mathrm{Ct}$ values for the PpsiBT1 qPCR assay were higher than the $\mathrm{Ct}$ values obtained for PpsiITS1 and PpsiITS2 assays (Table 4).

The best-performing qPCR assay PpsiITS1 was able to detect $P$. psidii from all the rust-infected Rhodomyrtus psidioides and Rhodamnia rubescens samples collected from Australia and herbarium samples of $S$. jambos and E. gacognei from New Caledonia (Table 5). The qPCR assay PpsiITS1 was also able to detect $P$. psidii from nonsymptomatic Rhodomyrtus psidioides leaves collected from an infected tree. The conventional $P$. psidii nested PCR assay also detected $P$. psidii in all rust-infected samples (Table 5).

Assay repeatability and reproducibility. The repeatability experiments for the qPCR assay PpsiITS1 across eight replicates of three dilutions $(500,5$, and $0.5 \mathrm{pg} / \mu \mathrm{l})$ of $P$. psidii DNA confirmed that the assay was repeatable and reproducible. The intra- and interassay CV for the qPCR assay PpsiITS1 were significantly low $(0.7$ to 1.3 and 0.8 to 1.6 , respectively; Table 6 ). Reproducibility of this qPCR assay was further confirmed as the assay was tested by using three different operators on different days in our laboratory and independently in different laboratories in New Zealand. Reproducible results were consistently obtained for the qPCR assay PpsiITS1 tested using the DNA extracted from urediniospores and P. psidii-infected samples from different laboratories in New Zealand (Table 7).

Development of duplex qPCR assay. The duplex assay developed for $P$. psidii and the cox gene was able to produce amplification of both targets in serial-diluted $P$. psidii DNA prepared in Eucalyptus sp. DNA. The Ct values obtained for $P$. psidii did increase when the duplex assay was tested at lower concentrations of $P$. psidii DNA with the addition of COX BLOCK at 0,300 , and $500 \mathrm{nM}$

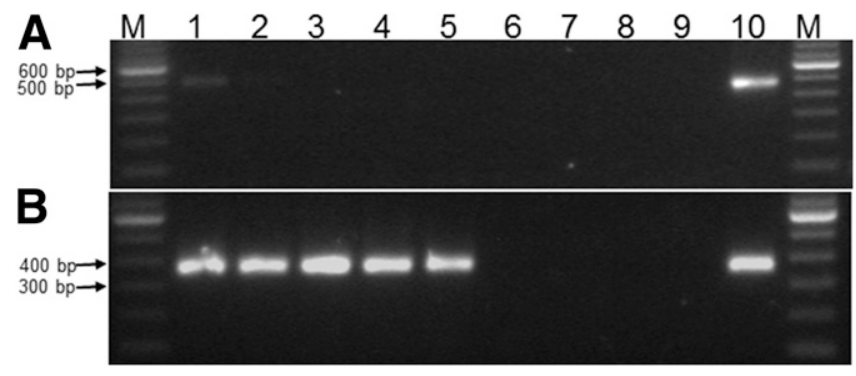

Fig. 3. Sensitivity of the Puccinia psidii nested polymerase chain reaction (PCR) assay. A, First PCR amplification with primers Ppsi1 and Ppsi6 and B, nested PCR amplification with primers Ppsi2 and Ppsi4. Lane 1, $11 \mathrm{ng}$ DNA; lane 2, $1.1 \mathrm{ng}$ DNA; lane 3, $110 \mathrm{pg}$ DNA; lane 4, $11 \mathrm{pg}$ DNA; lane 5, $1.1 \mathrm{pg}$ DNA; lane 6,110 fg DNA; lane 7, $11 \mathrm{fg}$ DNA; lane 8, $1.1 \mathrm{fg}$ DNA; lane 9, negative control; lane 10, P. psidii positive control; and lane M, 100-bp marker (Invitrogen).

Table 4. Polymerase chain reaction (PCR) detection of Puccinia psidii using real-time PCR assays PpsiITS1, PpsiITS2, and PpsiBT1from host (Eucalyptus sp.) DNA spiked with $P$. psidii DNA at different ratios

\begin{tabular}{lcccc}
\hline & \multicolumn{4}{c}{ Ct values for each qPCR } \\
\cline { 2 - 5 } DNA template mixture ${ }^{\mathbf{b}}$ & PpsiITS1 & PpsiITS2 & PpsiBT1 $^{\text {cox } \text { Gene }}$ \\
\hline $1: 0$ & 20.76 & 23.08 & 30.67 & NA \\
$1: 1$ & 22.08 & 24.50 & 31.64 & 22.88 \\
$1: 5$ & 23.65 & 26.15 & 33.24 & 22.69 \\
$1: 10$ & 24.59 & 27.03 & 34.19 & 22.66 \\
$1: 15$ & 25.14 & 27.46 & 34.72 & 22.75 \\
$1: 20$ & 25.38 & 27.70 & 35.20 & 23.14 \\
$0: 1$ & NA & NA & NA & 23.06 \\
Water & NA & NA & NA & NA \\
\hline
\end{tabular}

${ }^{\text {a }} \mathrm{NA}=$ not amplified.

b Ratio of $P$. psidii $(0.5 \mathrm{ng} / \mu \mathrm{l})$ to Eucalyptus sp. $(35 \mathrm{ng} / \mu \mathrm{l})$. 
(Table 8). However, the $\mathrm{Ct}$ values obtained for $P$. psidii in duplex assays with $750 \mathrm{nM}$ and $1 \mu \mathrm{M}$ COX BLOCK were similar to those in a $P$. psidii single qPCR assay (Table 8). The COX BLOCK addition to the duplex reactions at 500 and $750 \mathrm{nM}$ significantly delayed the cox gene amplification but $1 \mu \mathrm{M}$ COX BLOCK almost blocked the amplification. Thus, the duplex qPCR protocol for $P$. psidii and the cox gene was optimized with the addition of $750 \mathrm{nM}$ COX BLOCK. The optimized duplex qPCR assay was able to efficiently detect $P$. psidii from all myrtle-rust-infected plant tissues tested in this study.

\section{Discussion}

The aim of this study was to develop a highly sensitive, speciesspecific qPCR method that would allow for high-throughput detection of $P$. psidii directly from infected plant tissues. Novel TaqMan qPCR primers and probes based on ITS and $\beta$-tubulin DNA sequences have been developed and validated for the detection of $P$. psidii. All three qPCR assays were able to specifically detect $P$. psidii
DNA extracted from urediniospores as well as from infected plant tissues.

The ITS region was used as our primary target to design $P$. psidiispecific qPCR primers and probes because the ITS has been reported to provide a genomic region that is variable enough to differentiate between rust species (Maier et al. in press) and has been shown to be useful to develop specific PCR primers to detect $P$. psidii (Langrell et al. 2008). In addition, we also developed specific primers and probes that target $\beta$-tubulin sequences because they have been shown to be of value for species-specific qPCR for several fungal species (Aroca et al. 2008). The specificity of all three qPCR assays was extensively tested and shown to specifically amplify $P$. psidii from infected Myrtaceace plants. All three qPCR assays were able to detect $P$. psidii from all voucher samples regardless of their host and geographical origin. This included strains collected from different Myrtaceae plant species from Australia, Brazil, Hawaii, and New Caledonia. No cross amplification was produced from testing healthy

Table 5. Detection of Puccinia psidii from infected Myrtaceae plant samples with real-time polymerase chain reaction (PCR) assay (PpsilTS1) and nested PCR

\begin{tabular}{|c|c|c|c|c|c|c|}
\hline Sample & Host & Origin & Infection level $^{\mathbf{a}}$ & PpsiITS1 qPCR (Ct) & cox Gene qPCR $(\mathrm{Ct})^{b}$ & Nested PCR \\
\hline 1 & Rhodomyrtus psidioides & Australia & A & 33.75 & 25.96 & + \\
\hline 2 & R. psidioides & Australia & A & 31.95 & 23.80 & + \\
\hline 3 & R. psidioides & Australia & A & 31.46 & 24.30 & + \\
\hline 4 & R. psidioides & Australia & $\mathrm{B}$ & 28.55 & 27.91 & + \\
\hline 5 & R. psidioides & Australia & $\mathrm{B}$ & 29.21 & 27.17 & + \\
\hline 6 & R. psidioides & Australia & $\mathrm{B}$ & 29.01 & 26.76 & + \\
\hline 7 & R. psidioides & Australia & $\mathrm{C}$ & 28.71 & 26.74 & + \\
\hline 8 & R. psidioides & Australia & $\mathrm{C}$ & 30.56 & 26.12 & + \\
\hline 9 & R. psidioides & Australia & $\mathrm{C}$ & 29.94 & 25.91 & + \\
\hline 10 & R. psidioides & Australia & $\mathrm{D}$ & 19.61 & 24.76 & + \\
\hline 11 & R. psidioides & Australia & $\mathrm{D}$ & 23.38 & 26.40 & + \\
\hline 12 & R. psidioides & Australia & $\mathrm{D}$ & 27.57 & 27.63 & + \\
\hline 13 & R. psidioides & Australia & A & 33.87 & 21.06 & + \\
\hline 14 & R. psidioides & Australia & A & 34.98 & 22.60 & + \\
\hline 15 & R. psidioides & Australia & A & 32.06 & 22.22 & + \\
\hline 16 & R. psidioides & Australia & B & 28.39 & 28.90 & + \\
\hline 17 & R. psidioides & Australia & B & 29.76 & 26.03 & + \\
\hline 18 & R. psidioides & Australia & B & 26.12 & 27.63 & + \\
\hline 19 & R. psidioides & Australia & $\mathrm{C}$ & 26.24 & 27.16 & + \\
\hline 20 & R. psidioides & Australia & $\mathrm{C}$ & 31.08 & 28.82 & + \\
\hline 21 & R. psidioides & Australia & $\mathrm{C}$ & 30.80 & 26.12 & + \\
\hline 22 & R. psidioides & Australia & $\mathrm{D}$ & 17.59 & 21.94 & + \\
\hline 23 & R. psidioides & Australia & $\mathrm{D}$ & 31.32 & 27.45 & + \\
\hline 24 & R. psidioides & Australia & $\mathrm{D}$ & 22.88 & 25.14 & + \\
\hline 25 & R. psidioides & Australia & $\mathrm{D}$ & 20.78 & 22.18 & + \\
\hline 26 & R. psidioides & Australia & $\mathrm{D}$ & 20.45 & 22.33 & + \\
\hline 27 & R. psidioides & Australia & $\mathrm{D}$ & 28.69 & 23.75 & + \\
\hline 28 & R. psidioides & Australia & $\mathrm{D}$ & 27.30 & 27.20 & + \\
\hline 29 & R. psidioides & Australia & $\mathrm{D}$ & 22.54 & 21.86 & + \\
\hline 30 & R. psidioides & Australia & $\mathrm{D}$ & 18.14 & 22.10 & + \\
\hline 31 & R. psidioides & Australia & $\mathrm{D}$ & 28.34 & 20.47 & + \\
\hline 32 & R. psidioides & Australia & $\mathrm{D}$ & 21.86 & 21.37 & + \\
\hline 33 & Rhodamnia rubescens & Australia & A & 35.03 & 22.36 & + \\
\hline 34 & R. rubescens & Australia & A & 33.42 & 23.72 & + \\
\hline 35 & R. rubescens & Australia & B & 23.12 & 21.52 & + \\
\hline 36 & R. rubescens & Australia & B & 23.15 & 22.90 & + \\
\hline 37 & R. rubescens & Australia & $\mathrm{C}$ & 22.27 & 23.81 & + \\
\hline 38 & R. rubescens & Australia & $\mathrm{C}$ & 19.04 & 22.20 & + \\
\hline 39 & R. rubescens & Australia & $\mathrm{D}$ & 19.37 & 22.84 & + \\
\hline 40 & R. rubescens & Australia & $\mathrm{D}$ & 27.97 & 24.42 & + \\
\hline 41 & Syzygium jambos & New Caledonia & $\mathrm{D}$ & 17.76 & 24.40 & + \\
\hline 42 & S. jambos & New Caledonia & $\mathrm{D}$ & 17.72 & 23.98 & + \\
\hline 43 & Eugenia gocognei & New Caledonia & $\mathrm{D}$ & 19.24 & 24.74 & + \\
\hline 44 & E. gocognei & New Caledonia & $\mathrm{D}$ & 18.29 & 23.54 & + \\
\hline 45 & Sterile water & $\ldots$ & $\ldots$ & $\ldots$ & $\ldots$ & - \\
\hline
\end{tabular}

${ }^{a}$ Infection levels are visually estimated percentages of leaf area covered with rust pustules. A $=$ asymptomatic $(0 \%), \mathrm{B}=<15 \%$ leaf area covered with rust pustules, $\mathrm{C}=15$ to $30 \%$ leaf area covered with rust pustules, and $\mathrm{D}=>30 \%$ leaf area covered with rust pustules.

b qPCR amplification of plant internal control (cox gene) to check the quality of DNA extractions.

${ }^{\mathrm{c}}$ Species-specific PCR assay (Langrell et al. 2008): $+=$ presence of the specific PCR amplicon and $-=$ absence of the specific PCR amplicon. 
Myrtaceae plants or other closely related Puccinia spp. Recent studies using microsatellite markers to investigate the genetic diversity within $P$. psidii reported the occurrence of different genotypes in Brazil and a single genotype in Hawaii (Graça et al. 2011; Zhong et al. 2011). We are confident that our developed qPCR assays detect all strains because we have tested a number of $P$. psidii samples from different countries and different hosts. Furthermore, Langrell et al. (2008) found high levels of homogeneity in sequences of the ITS region among $P$. psidii regardless of host or geographic origin or genotype designation.

The detection sensitivities of the qPCR assays developed in this study varied significantly, where both ITS qPCR assays were 100 times more sensitive than the $\beta$-tubulin qPCR. This was expected because rDNA regions provide excellent detection targets due to their occurrence in multiple copies throughout the fungal genome, thereby enabling highly sensitive PCR amplification. It has been estimated that approximately 45 to 150 copies of the ITS region can be present in one haploid fungal genome and, for most species, it is around 50 copies (Ganley and Kobayashi 2007). The qPCR assay PpsiITS1 showed greater analytical sensitivity than the other two qPCR assays and was selected as the best-performing qPCR assay. Although the detection sensitivity of the $\beta$-tubulin qPCR assay was low, this assay will still be useful as a second gene confirmatory assay for new detections of $P$. psidii. The detection level of nested PCR assay for $P$. psidii was reported to be approximately $0.1 \mathrm{pg}$ (Langrell et al. 2008), which is theoretically equal to one urediniospore of $P$. graminis $\mathrm{f}$. sp. tritici (Backlund and Szabo 1993). In this study, sensitivity obtained for the previously published $P$. psidii-specific nested PCR assay was $1.1 \mathrm{pg}$ of genomic DNA. The difference in reported detection limits could be due to several factors, including different diseased plant tissue types, DNA extraction methods, or PCR reagents, or variation

Table 6. Intra- and interassay coefficients of variation (CV) based on the mean cycle threshold values calculated for the real-time polymerase chain reaction assay PpsiITS1 tested with eight replicates of each Puccinia psidii DNA

\begin{tabular}{lcc}
\hline & \multicolumn{2}{c}{$\mathbf{C V}(\%)$} \\
\cline { 2 - 3 } $\boldsymbol{P}$ psidii DNA $(\mathbf{p g} / \boldsymbol{\mu l})$ & Intraassay & Interassay \\
\hline 500 & 1.3 & 1.3 \\
5 & 0.7 & 0.8 \\
0.05 & 1.1 & 1.6 \\
\hline
\end{tabular}

between PCR instruments. However, the sensitivity of the $P$. psidii qPCR assay PpsiITS1 was 10 times more sensitive when compared with the previously published nested PCR assay for $P$. psidii.

The qPCR assays enabled specific and sensitive detection of $P$. psidii in the presence of host DNA. Initially, the qPCR assays were evaluated using DNA from host plant tissue artificially spiked with $P$. psidii DNA due to unavailability of naturally infected plants in New Zealand. Later, the best-performing qPCR assay PpsiITS1 was tested in Australia and New Zealand on P. psidii-infected plant material and herbarium samples of myrtle-rust-infected plant material collected from a recent outbreak in New Caledonia. All these samples were from different Myrtaceae species and the qPCR assay PpsiITS1 was able to consistently detect $P$. psidii from all samples, including nonsymptomatic leaf tissue collected from an infected plant. The repeatability and reproducibility of this assay was further confirmed in our laboratory and by testing in two other laboratories in New Zealand and Australia (data not shown), and the results were comparable. In general, the assays showed a high level of robustness because using different thermocyclers or changing DNA extraction method and PCR reagents had little influence on overall results.

In addition, the qPCR assays described here incorporate the use of an internal control to ensure that the quality of the nucleic acid extracted from plant tissue is PCR competent, thereby eliminating false-negative results due to inhibition of the PCR. A plant internal PCR control based on primers to amplify the cox gene has been commonly used to check the PCR quality of nucleic acid extractions (Weller et al. 2000). In most cases, two separate PCR amplifications (target and cox gene) are required, which necessitates additional reagents and time. In this study, a duplex qPCR assay developed for $P$. psidii and the cox gene using an additional PCR ingredient (COX BLOCK) was able to amplify both targets in a single reaction without compromising the analytical sensitivity of the $P$. psidii single qPCR assay. The COX BLOCK is a patented PCR ingredient (dNature Diagnostics \& Research, Ltd.) which delays the cox gene amplification until a substantial amount of target (pathogen) amplification is achieved. The duplex assay was tested against the nucleic acid extracted from myrtle-rust-infected plant materials and the results were comparable with $P$. psidii single $\mathrm{qPCR}$ detection. Compared with the previously published conventional nested PCR assay for $P$. psidii, both the single and duplex qPCR assays are faster and are less prone to contamination because no postamplification processing steps are required.

Table 7. Interlaboratory comparison of Cycle threshold $(\mathrm{Ct})$ values for the real-time polymerase chain reaction assay PpsiITS1 tested in different laboratories using different Puccinia psidii DNA extractions ${ }^{\mathrm{a}}$

\begin{tabular}{|c|c|c|c|c|c|c|}
\hline \multirow[b]{2}{*}{ Sample } & \multirow[b]{2}{*}{ Host } & \multirow[b]{2}{*}{ DNA from } & \multicolumn{2}{|c|}{ DNA $\left(10^{-1}\right)$} & \multicolumn{2}{|c|}{ DNA $\left(10^{-2}\right)$} \\
\hline & & & Lab 1 & $\overline{\text { Lab } 2}$ & Lab 1 & $\overline{\text { Lab } 2}$ \\
\hline 1 & Melaleuca viridiflora & Urediniospores & 23.20 & 22.66 & 26.10 & 26.06 \\
\hline 2 & Rhodomyrtus psidioides & Infected tissue & 27.57 & 26.29 & 31.37 & 31.00 \\
\hline 3 & Syzygium jambos & Infected tissue & 24.11 & 23.24 & 27.74 & 27.11 \\
\hline 4 & S. jambos & Infected tissue & 24.48 & 24.16 & 27.37 & 28.39 \\
\hline
\end{tabular}

Table 8. Comparison of cycle threshold (Ct) values for Puccinia psidii and the cox gene for real-time polymerase chain reaction (qPCR) assay PpsiITS1 and duplex qPCR assay with different concentrations of COX BLOCK

\begin{tabular}{|c|c|c|c|c|c|c|c|c|c|}
\hline \multirow[b]{3}{*}{ DNA $(\mathrm{pg} / \mu \mathrm{l})^{\mathrm{b}}$} & \multirow{3}{*}{$\frac{\mathrm{qPCR}}{P p s i}$} & \multicolumn{8}{|c|}{ Concentrations of COX BLOCK in duplex $q \mathrm{PCR}^{\mathrm{a}}$} \\
\hline & & \multicolumn{2}{|c|}{$\mathbf{0}$} & \multicolumn{2}{|c|}{$500 \mathrm{nM}$} & \multicolumn{2}{|c|}{$750 \mathrm{nM}$} & \multicolumn{2}{|c|}{$1 \mu \mathrm{M}$} \\
\hline & & Ppsi & $\operatorname{cox}$ & Ppsi & $\operatorname{cox}$ & Ppsi & $\operatorname{cox}$ & Ppsi & $\operatorname{cox}$ \\
\hline 500 & 20.37 & 21.22 & 18.75 & 20.25 & 22.38 & 21.96 & 31.60 & 20.34 & 32.65 \\
\hline 50 & 23.83 & 26.71 & 18.67 & 24.12 & 22.26 & 24.31 & 29.15 & 23.30 & 31.11 \\
\hline 5 & 27.29 & 30.76 & 18.34 & 29.16 & 22.24 & 27.37 & 28.77 & 27.54 & 31.06 \\
\hline 0.5 & 30.87 & 34.62 & 18.37 & 34.02 & 22.27 & 30.72 & 28.58 & 30.49 & 31.06 \\
\hline
\end{tabular}

${ }^{\text {a }}$ Ct values of $P$. psidii amplification (Ppsi) and plant cox gene amplification (cox).

b $P$. psidii DNA concentration, consisting of $P$. psidii genomic DNA diluted in a background of Eucalyptus sp. DNA. 
The duplex qPCR assay for $P$. psidii had a shorter run time (55 min) than the $P$. psidii single qPCR assay ( $1 \mathrm{~h}$ and $15 \mathrm{~min})$ and the conventional nested-PCR assay $(6 \mathrm{~h})$. This duplex qPCR assay will be particularly useful to facilitate high-throughput detection by increasing the number of samples that could be tested in a single qPCR run with the potential to process and analyze up to 96 samples within $4 \mathrm{~h}$.

$P$. psidii is a quarantine pathogen in many countries, including New Zealand, and it is important to have fast and accurate detection tools to identify this pathogen in order to maximize the chances of a successful containment or eradication. Detection of a quarantine pathogen during an outbreak is time sensitive and may require hundreds of samples to be immediately tested. In previous responses, we have found that using conventional PCR is particularly cumbersome for high-throughput detection; for example, detection of Pseudomonas syringae pv. actinidiae on kiwifruit (Taylor et al. 2014). Some of the main disadvantages of using conventional PCR were a reduced detection sensitivity compared with qPCR, increased risk of cross contamination or false positive results from PCR product carryover, and the use of electrophoresis in the detection phase resulting in longer processing times. During the $P$. syringae pv. actinidiae response, there was only a conventional PCR assay available for the detection of $P$. syringae pv. actinidiae. Significant resources were required to rapidly develop and validate a $\mathrm{qPCR}$ assay to test thousands of kiwifruit samples within a short period of time. This removed resources from other response activities and, ultimately, delayed test results, emphasizing the need for continual improvement of diagnostic protocols for the high-throughput detection of quarantine pathogens.

Early and sensitive detection of myrtle rust will provide one of the few opportunities to prevent establishment of this disease. We believe that qPCR could provide a method of detection to identify infected material prior to fungal sporulation and, thereby, reduce potential spread of the fungus. New Zealand is currently free of myrtle rust; however, since the first detection of Puccinia psidii in Australia, the country is under threat of an incursion from this pathogen. A study by Kriticos and Leriche (2008) indicated that much of the North Island and some of the South Island of New Zealand appear to be climatically suitable for P. psidii. Similar to other Puccinia spp., $P$. psidii can spread by wind dissemination of infectious urediniospores from infected areas. Detection by microscopic examination of urediniospores collected from spore traps has been used in the field to estimate the wind dispersal of $P$. psidii urediniospores and to monitor the spread of myrtle rust disease in Brazil (Zauza et al. 2015). The $P$. psidii qPCR assays developed in this study could be used along with spore traps for more accurate and sensitive detection of $P$. psidii in monitoring high-risk areas. Other studies using qPCR to detect and monitor rust fungi in sugarcane have successfully detected Puccinia spp. prior to uredinia development and symptom expression (Glynn et al. 2010). Such detections could prove useful for eradication, containment, or disease management strategies because it would allow the early destruction of infected material, or allow movement controls to be put in place and the use of protective fungicides to limit the spread of inoculum.

To our knowledge, this is the first qPCR assay developed for $P$. psidii, thereby providing a rapid and sensitive tool for its detection. This assay was demonstrated to be highly sensitive, specific, and reliable and was able to detect $P$. psidii before disease symptom expression and rust spore production. Consequently, qPCR will have the potential for use during presymptomatic monitoring of myrtle rust and for screening nursery stocks for import and exports. Presymptomatic screening of plant material in post entry quarantine or at high-risk surveillance sites may play an important role in successful containment or possible eradication of the myrtle rust pathogen.

\section{Acknowledgments}

This research was funded by Operational Research Programmes, Ministry for Primary Industries, New Zealand. We thank A. C. Alfenas (Department of Plant Pathology, Federal University of Viçosa, Brazil), C. Kadooka (University of Hawaii), and A. McTaggart (Department of Agriculture, Fisheries and Forestry,
Brisbane, Australia) for providing $P$. psidii DNA samples; E. Nakamura (Department of Veterinary, Food and Rural Affairs, New Caledonia) for providing P. psidii herbarium samples; J. Henderson (Queensland Alliance for Agriculture and Food Innovation, Australia) for helping to perform qPCR tests in Australia; M. Padamsee (Landcare Research, New Zealand) for providing DNA of Puccinia spp. for testing; S. Addison (Scion, New Zealand) for technical assistance; and S. Keeling and M. Toome for critically reviewing the manuscript.

\section{Literature Cited}

Aime, M. C. 2006. Toward resolving family-level relationships in rust fungi (Uredinales). Mycoscience 47:112-122.

Anikster, Y., Sazbo, L. J., Eilam, T., Manisterski, J., Koike, S. T., and Bushnell, W. R. 2004. Morphology, life cycle biology, and DNA sequence analysis of rust fungi on garlic and chives from California. Phytopathology 94:569-577.

Aroca, A., Raposo, R., and Lunello, P. 2008. A biomarker for the identification of four Phaeoacremonium species using the beta-tubulin gene as the target sequence. Appl. Microbiol. Biotechnol. 80:1131-1140.

Backlund, J. E., and Szabo, L. J. 1993. Physical characteristics of the genome of the phytopathogenic fungus Puccinia graminis. Curr. Genet. 24:89-93.

Capote, N., Pastrana, A. M., Aguado, A., and Sánchez-Torres, P. 2012. Molecular tools for detection of plant pathogenic fungi and fungicide resistance. Pages 151-202 in: Plant Pathology. C. J. Cumagun, ed. Online publication. InTech.

Carnegie, A. J., and Cooper, K. 2011. Emergency response to the incursion of an exotic myrtaceous rust in Australia. Australas. Plant Pathol. 40: 346-359.

Carnegie, A. J., and Lidbetter, J. R. 2012. Rapidly expanding host range for Puccinia psidii sensu lato in Australia. Australas. Plant Pathol. 41:13-29.

Carnegie, A. J., Lidbetter, J. R., Walker, J., Horwood, M. A., Tesoriero, L., Glen, M., and Priest, M. J. 2010. Uredo rangelii, a taxon in the guava rust complex, newly recorded on Myrtaceae in Australia. Australas. Plant Pathol. 39:463-466.

Coutinho, T. A., Wingfield, M. J., Alfenas, A. C., and Crous, P. W. 1998 Eucalyptus rust: A disease with the potential for serious international implications. Plant Dis. 82:819-825.

Furtado, E. L., and Marino, C. L. 2003. Eucalyptus rust management in Brazil. In: Proceedings $2^{\text {nd }}$ IUFRO Rusts of Forest Trees. WP Conference, August 2002, Yangling, China. For. Res. 16 (Suppl.):118-124.

Ganley, A. R., and Kobayashi, T. 2007. Highly efficient concerted evolution in the ribosomal DNA repeats: Total rDNA repeat variation revealed by wholegenome shotgun sequence data. Genome Res. 17:184-191.

Giblin, F. 2013. Myrtle rust report: Assessment of myrtle rust situation in New Caledonia. Online publication. University of the Sunshine Coast, Maroochydore, Queensland, Australia. http://www.davar.gouv.nc/portal/ page/portal/davar/librairie/fichiers/25074187.PDF

Giblin, F., and Carnegie, A. J. 2014. Puccinia psidii (Myrtle Rust)—Australian host list. Online publication, http://www.anpc.asn.au/myrtle-rust

Glen, M., Alfenas, A. C., Zauza, E. A. V., Wingfield, M. J., and Mohammed, C. 2007. Puccinia psidii: A threat to the Australian environment and economy-A review. Australas. Plant Pathol. 36:1-16.

Glynn, N. C., Dixon, L. J., Castlebury, L. A., Szabo, L. J., and Comstock, J. C. 2010. PCR assays for the sugarcane rust pathogens Puccinia kuehnii and $P$. melanocephala and detection of a SNP associated with geographical distribution in P. kuehnii. Plant Pathol. 59:703-711.

Graça, R. N., Alfenas, A. C., Ross-Davis, A. L., Klopfenstein, N. B., Kim, M. S., Peever, T. L., Cannon, P. G., Uchida, J. Y., Kadooka, C. Y., and Hauff, R. D. 2011. Multilocus genotypes indicate differentiation between Puccinia psidii populations from South America and Hawaii. Pages 131-134 in: Proc. 58th West. Int. For. Dis. Work Conf. Canada.

Henson, J. M., and French, R. 1993. The polymerase chain reaction and plant disease diagnosis. Annu. Rev. Phytopathol. 31:81-109.

Kawanishi, T., Uematsu, S., Kakishima, M., Kagiwada, S., Hamamoto, H., Horie, H., and Namba, S. 2009. First report of rust disease on ohia and the causal fungus, Puccinia psidii, in Japan. J. Gen. Plant Pathol. 75:428-431.

Kriticos, D. J., and Leriche, A. 2008. The current and future potential distribution of Guava Rust, Puccinia psidii in New Zealand. A report prepared for the Ministry of Agriculture and Forestry. MAF Biosecurity N. Z. Tech. Pap. No. 2009/28. Online publication. CSIRO, Kingston, Australia. http://www.biosecurity. govt.nz/files/publications/technical-papers/future-distribution-of-guava-rust.pdf

Kropp, B. R., Hansen, D. R., Wolf, P. G., Flint, K. M., and Thomson, S. V. 1997. A study on the phylogeny of the dyer's woad rust fungus and other species of Puccinia from crucifers. Phytopathology 87:565-571.

Langrell, S. R. H., Glen, M., and Alfenas, A. C. 2008. Molecular diagnosis of Puccinia psidii (guava rust)-A quarantine threat to Australian eucalypt and Myrtaceae biodiversity. Plant Pathol. 57:687-701.

Maier, W., McTaggart, A. R., Roux, J., and Wingfield, M. J. Phakopsora myrtacearum sp. nov., a newly described rust (Pucciniales) on eucalypts in eastern and southern Africa. Plant Pathol. In press.

Martins, M. V. V., Silveira, S. F., Maffia, L. A., Rocabado, J. M. A., and MussiDias, V. 2011. Chemical control of guava rust (Puccinia psidii) in the Northern Region of Rio de Janeiro State, Brazil. Australas. Plant Pathol. 40:48-54.

Rayachhetry, M. B., Elliott, M. T., and Van, T. K. 1997. Natural epiphytotic of the rust Puccinia psidii in Melaleuca quinquenervia in Florida. Plant Dis. 81:831. 
Roux, J., Greyling, I., Coutinho, T. A., Verleur, M., and Wingfield, M. J. 2013. The Myrtle rust pathogen, Puccinia psidii, discovered in Africa. IMA Fungus 4:155-159.

Simpson, J. A., Thomas, K., and Grgurinovic, C. A. 2006. Uredinales species pathogenic on species of Myrtaceae. Australas. Plant Pathol. 35:549-562.

Taylor, R. K., Chapman, J. R., Romberg, M. K., Weir, B. S., Vanneste, J. L., Everett, K. R., Ward, L. I., Liefting, L. W., Lebas, B. S. M., and Alexander, B. J. R. 2014. Diagnostic challenges for the detection of emerging pathogens: A case study involving the incursion of Pseudomonas syringae pv. actinidiae in New Zealand. Pages 71-86 in: Detection and Diagnostics of Plant Pathogens. Plant Pathology in the 21st Century, Vol. 5. M. L. Gullino and P. Bonants, eds. Online publication. Springer, The Netherlands.

Tommerup, I. C., Alfenas, A. C., and Old, K. M. 2003. Guava rust in Brazil-A threat to Eucalyptus and other Myrtaceae. N. Z. J. For. Sci. 33:420-428.

Uchida, J., Zhong, S., and Killgore, E. 2006. First report of a rust disease on Ohi'a caused by Puccinia psidii in Hawaii. Plant Dis. 90:524.

Viljanen-Rollinson, S. L. H., and Cromey, M. G. 2002. Pathways of entry and spread of rust pathogens: Implications for New Zealand's biosecurity. N. Z. Plant Prot. 55:42-48.
Weller, S. A., Elphinstone, J. G., Smith, N. C., Boonham, N., and Stead, D. E. 2000. Detection of Ralstonia solanacearum strains with a quantitative, multiplex, real-time, fluorogenic PCR (TaqMan) assay. Appl. Environ. Microbiol. 66:2853-2858.

Wilkinson, A. G., and Spiers, A. G. 1976. Introduction of the poplar rusts Melampsora larici-populini and M. medusae to New Zealand and their subsequent distribution. N. Z. J. Sci. 19:195-198.

Winter, G. 1884. Repertorium. Rabenhorsti Fungi europaei et extraeuropaei. Cent. XXXI et XXXII. cura Dr G. Winter. Hedwigia 23:164-175.

Zambino, P. J., and Szabo, L. J. 1993. Phylogenetic relationships of selected cereal and grass rusts based on rDNA sequence analysis. Mycologia 85:401-414.

Zauza, E. A. V., Lana, V. M., Maffia, L. A., Araujo, M. M. F. C., Alfenas, R. F., Silva, F. F., and Alfenas, A. C. 2015. Wind dispersal of Puccinia psidii urediniospores and progress of eucalypt rust. For. Pathol. 45:102-110.

Zhong, S., Yang, B., and Puri, K. D. 2011. Characterization of Puccinia psidii isolates in Hawaii using microsatellite DNA markers. J. Gen. Plant Pathol 77:178-181.

Zhuang, J. Y., and Wei, S. X. 2011. Additional materials for the rust flora of Hainan Province, China. Mycosystema 30:853-860. 